\title{
TOXIC AND REPELLENT EFFECT OF HARMAL (Peganum harmala L.) ACETONIC EXTRACT ON SEVERAL APHIDS AND Tribolium castaneum (HERBST)
}

\author{
Elham Salari ${ }^{1,2 *}$, Kamal Ahmadi ${ }^{1}$, Reza Zamani Dehyaghobi ${ }^{1,2}$, Amin Purhematy ${ }^{1}$, \\ and Haji Mohammad Takalloozadeh ${ }^{1}$
}

To reduce the dependence on the sometimes unwise use of synthetic pesticides in fruit and vegetable plantations, the toxicity and repellence of Peganum harmala L. (Zygophyllaceae) acetonic seed extract was assayed against several insect pests. For contact toxicity, 3- to 4-d-old individuals of Aphis fabae Scopoli, A. gossypii Glover, A. nerii Boyer de Fonscolombe, and Myzus persicae (Sulzer) were included, as well as 1- to 7-d-old adult Tribolium castaneum (Herbst). Repellent effect experiments were conducted on adult, 1- to 2- and 3- to 4-d old M.persicae individuals. At $60 \mathrm{mg} \mathrm{mL}^{-1}$, the topical bioassay mortality percentage was significantly higher in A. gossypii than in A. fabae and A. nerii after 12-72 h. Mortality of the treatments on $M$. persicae was $87.1 \%$ and $90.0 \%$ after 24 and $48 \mathrm{~h}$, respectively, and significantly higher than $A$. fabae and A. nerii during this period. At $60 \mathrm{mg} \mathrm{mL}^{-1}$, the mortality of $T$. castaneum was much lower than that of the aphid species. The highest repellent index (over 72\%) was observed on 1- to 2-d-old M.persicae individuals.

Key words: Peganum harmala, topical bioassay, aphid species, Tribolium castaneum, Aphis fabae, Aphis gossypii, Aphis nerii, Myzus persicae.

$\mathrm{T}$ he widespread use of synthetic pesticides has led to several adverse effects such as food, soil, ground water, and air contamination with toxic residues, which have side effects on non-target insects and other organisms (Bughio and Wilkins, 2004). To overcome these problems, it is necessary to seek safe, convenient, environmental, and low-cost alternative pest control methods. Considerable efforts have focused on plant-derived materials that are potentially useful as commercial insecticides. Plant derivatives are less toxic or nontoxic to mammals, other vertebrates, and invertebrates. Plant products have several uses in insect control. These products have also been studied for acute toxicity, antifeedant, or repellent, attractant, and fumigant effects, as well as inhibiting reproduction of many pest species (Cox, 2004; Kubo, 2006). The structural diversity and bioactivity of plant alkaloids, such as in Peganum harmala L. (Zygophyllaceae), makes them one of the most important groups of natural origin substances.

Peganum harmala is a perennial glabrous herb that grows in semi-arid conditions, steppe areas, and sandy soils. It has frequently been used in traditional medicine and as an abortive agent (Lamchouri et al., 2002). In Iran,

${ }^{1}$ Shahid Bahonar University of Kerman, Agriculture College, 22 Bahman Blv., Kerman, Iran.

*Corresponding author (salari_elham@hotmail.com).

${ }^{2}$ Member of Young Researchers Society, Shahid Bahonar University of Kerman, 22 Bahman Blv., Kerman, Iran.

Received: 20 May 2011.

Accepted: 14 November 2011. dried capsules - mixed with other ingredients- are burnt to produce scented smoke that is used to purify the air and the mind, but it is mostly used as a charm against "the evil eye" (Frison et al., 2008).

Peganum harmala is a rich source of b-carboline and quinazoline alkaloids (Kartal et al., 2003). The possible use of $P$. harmala in modern phyto-indole entheogen preparations is correlated to its b-carboline content: harmine, harmaline, and tetrahydroharmine (THH), collectively known as harmala alkaloids, which are mostly found in the seeds and roots. Harmine and harmaline are competitive and reversible inhibitors of monoamine oxidase type-A (MAO-A) enzymes, whereas THH is believed to inhibit serotonin uptake (Buckholtz and Boggan, 1977; Kim et al., 1997). Regarding its toxicity against different insects, Abbassi et al. (2003) found the toxic effect of $P$. harmala on the survival, feeding, behavior, and reproduction of the desert locust, Schistocerca gregaria (Forskal) (Orthoptera: Acrididae), under laboratory conditions. Jbilou et al. (2006) found that methanol extracts from different medicinal plants, including $P$. harmala seeds, have insecticidal effects on the larvae and adults of the stored grain pest Tribolium castaneum Herbst (Coleoptera: Tenebrionidae) after a period of time.

Although aphids are major vectors of viral diseases and serious pests for many cultivated plants worldwide, there is little knowledge in the literature about the effect of a plant extract such as $P$. harmala against aphids. Salari et al. (2010) found the toxic effect of Otostegia persica (Burmeister) Boissduval (Labiatae) acetonic 
extract on some aphid species. Several authors have tested some plant-derived compounds such as aphid repellents. Gutiérrez et al. (1997) tested bisabolene, farnesol, and geraniol in assays using apterous Myzus persicae (Sulzer) (Hemiptera: Aphididae) and leaf discs embedded in agar.

This study bioassayed the toxicity of $P$. harmala seed extract on several aphids and on the red flour beetle $T$. castaneum; it also determined the repellent effect of this plant against $M$. persicae.

\section{MATERIALS AND METHODS}

\section{Plant extract preparation}

Plant material $(800 \mathrm{~g})$, collected in Iran's Kerman province $\left(30^{\circ} 19^{\prime} 51.33^{\prime \prime} \mathrm{N}, 5^{\circ} 55^{\prime} 41.72 ”\right.$ E, 1776 m.a.s.1.) in August 2010, was dried at room temperature under shade conditions for $1 \mathrm{wk}$ until crisp. Then, 50 $\mathrm{g}$ of dried seeds were ground and powdered with an electric stainless steel blender for $5 \mathrm{~min}$ and placed in a $500 \mathrm{~mL}$ Erlenmeyer flask with $90 \mathrm{~mL} 99.9 \%$ acetone for extraction. The mixture was filtered with Whatman $\mathrm{N}^{\circ}$ 91 filter paper, and the residues were soaked and shaken again in $10 \mathrm{~mL}$ acetone for $2 \mathrm{~h}$ (total $50 \mathrm{~g}$ seeds:100 $\mathrm{mL}$ acetone). The solution was filtered again over a new filter, and the first and second filtrates were mixed and concentrated in $15 \mathrm{~cm}$ diameter Petri dishes under a laboratory hood for $24 \mathrm{~h}$ to obtain $3.55 \mathrm{~g}$ dry residue (total $7.1 \%$ yield percentage) that was stored at $4{ }^{\circ} \mathrm{C}$. A specific volume of this dry residue was used in distilled water and dimethyl sulfoxide (DMSO) to make different concentrations for each test.

\section{Insect rearing}

The insects in this study were the Aphis fabae Scopoli, Aphis gossypii Glover, Aphis nerii Boyer de Fonscolombe, and M. persicae (Hemiptera: Aphididae) aphids, and the red flour beetle T. castaneum .

The aphid species colony in this study came from Shahid Bahonar University field infestation and, after identification, a stock culture was maintained on broad beans Vicia faba L. cv. Aquadulce. They were placed on freshly excised $4.5 \mathrm{~cm}$ diameter broad bean leaf discs set in $5.5 \mathrm{~cm}$ diameter plastic Petri dishes with a $0.5 \mathrm{~cm}$ thick layer of $0.7 \%$ agar gel, with a meshed hole in the lid to allow air exchange, and were reared in a growth chamber at $25 \pm 1$ ${ }^{\circ} \mathrm{C}, 60 \pm 10 \%$ relative humidity, and $16 \mathrm{~h}$ of artificial light at an intensity of about 4000 lux. The relatively susceptible of 3- to 4-d-old A.fabae, A. gossypii, A. nerii, and M.persicae individuals were employed for the experiments.

Tribolium castaneum was reared on wheat flour at room temperature. for the experiments, 1- to 7-d-old adult insects were used.

Bioassays with plant extracts

Topical application. Direct contact toxicity was tested by topically applying the $P$. harmala acetonic seed extract with a micropipette on the top of the abdomen of the relatively susceptible 3 - to 4-d-old A. fabae, A. gossypii, $A$. nerii, and $M$. persicae individuals, as well as on the thorax of 1- to 7-d-old adult T. castaneum. A concentration of $60 \mathrm{mg} \mathrm{mL}^{-1}$ for aphids and two concentrations of 60 and $120 \mathrm{mg} \mathrm{mL}^{-1}$ for the red flour beetle were applied. The experiments were carried out under bioassay laboratory conditions at $25 \pm 1{ }^{\circ} \mathrm{C}, 60 \pm 10 \%$ relative humidity, and $16 \mathrm{~h}$ of artificial light at an intensity of about 4000 lux. Only distilled water and dimethyl sulfoxide (DMSO) were applied in the control treatments. Each treatment had 20 replicates and each replicate included 10 insects. Aphid mortality was determined after 12, 24, 48, and 72 $\mathrm{h}$, and after $2,12,24,48$, and $72 \mathrm{~h}$ from the beginning of exposure for $T$. castaneum. Insects were considered dead when no leg or antennal movements were observed.

Repellent effect experiment. The dual choice test was conducted to measure the repellent effect of the $P$. harmala extract on adults of relatively susceptible 3 - to 4-d-old and 1- to 2-d-old M.persicae individuals. In each experiment, 20 insects were released in the middle of withered broad bean leaf discs that were placed on top of cotton tying tape $(12 \mathrm{~cm})$ linkage in two round plastic Petri dishes $(5.5 \mathrm{~cm}$ diameter $)$, one as a treatment and the other as a control. The round plastic Petri dishes, with freshly excised broad bean leaf discs $(4.5 \mathrm{~cm}$ diameter $)$, were filled with a $0.5 \mathrm{~cm}$ thick layer of $0.7 \%$ agar gel. In the treatments, only a minute quantity of pure extract was applied with a micropipette at the end of its cotton tying tape and on the leaf disc, while only distilled water was applied in the control. The round plastic Petri dishes were positioned in a Plexiglas cage $(15 \times 7.5 \times 4.5 \mathrm{~cm})$ during a trial. Experiments were replicated 10 times. After 48 $\mathrm{h}$, the number of insects was counted in the treated (T) and control (C) Petri dishes. The repellent index (RI) was calculated by the following formula: $\mathrm{RI}=[(\mathrm{C}-\mathrm{T}) / \mathrm{C}+\mathrm{T})]$ $\times 100$ (Pascual-Villalobos and Robledo, 1998). Positive and negative values indicate repellent and attractant effects, respectively.

\section{Statistical analysis}

Mortality data were adjusted for mortality in the control by Abbott's (Abbott, 1925) correction, and was calculated as: $\mathrm{M}_{\mathrm{a}}(\%)=\left[\left(\mathrm{M}_{\mathrm{t}}-\mathrm{M}_{\mathrm{c}}\right) /\left(100-\mathrm{M}_{\mathrm{c}}\right)\right] \times 100$ where $\mathrm{M}_{\mathrm{a}}$ is corrected mortality (\%), $\mathrm{M}_{\mathrm{t}}$ is mortality in the treatment $(\%)$, and $\mathrm{M}_{\mathrm{c}}$ is mortality in the control (\%). Mortality and repellency data were subjected to a one-way ANOVA and followed by the Tukey and Fisher tests (StatPlus 4.9, 2007, Croydon, UK), respectively.

\section{RESULTS}

\section{Topical bioassay}

The effect of the $P$. harmala acetonic seed extract among 
aphid species after $12-72 \mathrm{~h}$ is shown in Table 1 . This extract was highly toxic against $A$. gossypii since it was able to kill $95 \%$ after $72 \mathrm{~h}$. At $60 \mathrm{mg} \mathrm{mL}^{-1}$, mortality after $12-72 \mathrm{~h}$ was significantly higher $(\mathrm{P} \leq 0.05)$ in A. gossypii than A. fabae and A. nerii. Mortality of A. gossypii was $88.0 \%$ after $12 \mathrm{~h}$, while it was $67.7 \%$ and $57.0 \%$ in $A$. fabae and $A$. nerii, respectively. Mortality of $M$. persicae was $87.1 \%$ and $90.0 \%$ after 24 and $48 \mathrm{~h}$, respectively, and significantly higher $(\mathrm{P} \leq 0.05)$ than $A$. fabae and $A$. nerii. The mortality of $A$. nerii treatments after $72 \mathrm{~h}$ was $80 \%$, which was significantly higher $(\mathrm{P} \leq 0.05)$ than after $12 \mathrm{~h}$.

Significant differences in $T$. castaneum mortality to the $P$. harmala extract occurred between 60 and $120 \mathrm{mg}$ $\mathrm{mL}^{-1}$ after $2-72 \mathrm{~h}(\mathrm{P} \leq 0.05)$, although it did not differ significantly in each time exposure period (Figure 1). At $120 \mathrm{mg} \mathrm{mL}^{-1}$, mortality was $27.5 \%$ after $72 \mathrm{~h}$, and $8.0 \%$ at $60 \mathrm{mg} \mathrm{mL}^{-1}$. At this concentration, $T$. castaneum mortality was much less than the four aphid species.

\section{Dual choice bioassay}

The results of the dual choice bioassay are shown in Figure 2 expressed as repellent index (RI) of the extracts at $48 \mathrm{~h}$ after application on different developmental

Table 1. Mortality of aphid species after exposure to Peganum harmala acetonic seed extract $\left(60 \mathrm{mg} \mathrm{mL}^{-1}\right)$.

\begin{tabular}{lllll}
\hline \multirow{2}{*}{$\begin{array}{l}\text { Time after } \\
\text { treatment } \\
(\mathrm{h})\end{array}$} & \multicolumn{4}{c}{ Mortality (\%) (Mean $\pm \mathrm{SE})$} \\
\cline { 2 - 5 } & Aphis fabae & Aphis gossypii & Aphis nerii & Myzus persicae \\
\hline 12 & $67.7 \pm 5.39 \mathrm{Abc}$ & $88.0 \pm 3.37 \mathrm{Aa}$ & $57.0 \pm 5.28 \mathrm{Ac}$ & $81.4 \pm 5.33 \mathrm{Aab}$ \\
24 & $67.7 \pm 5.39 \mathrm{Ab}$ & $91.0 \pm 3.06 \mathrm{Aa}$ & $65.0 \pm 5.00 \mathrm{ABb}$ & $87.1 \pm 3.38 \mathrm{Aa}$ \\
48 & $71.1 \pm 5.65 \mathrm{Ab}$ & $94.0 \pm 2.10 \mathrm{Aa}$ & $73.0 \pm 5.08 \mathrm{ABb}$ & $90.0 \pm 2.77 \mathrm{Aa}$ \\
72 & $71.1 \pm 5.65 \mathrm{Ab}$ & $95.0 \pm 1.98 \mathrm{Aa}$ & $80.0 \pm 4.35 \mathrm{Bb}$ & $90.0 \pm 2.77 \mathrm{Aab}$ \\
\hline
\end{tabular}

Means in columns followed by different lower case letters indicate significant differences between the different biotests within the same time period. Means in columns followed by different upper case letters indicate significant differences between the time periods within the same biotests at $(\mathrm{P} \leq 0.05)$ (one-way ANOVA)

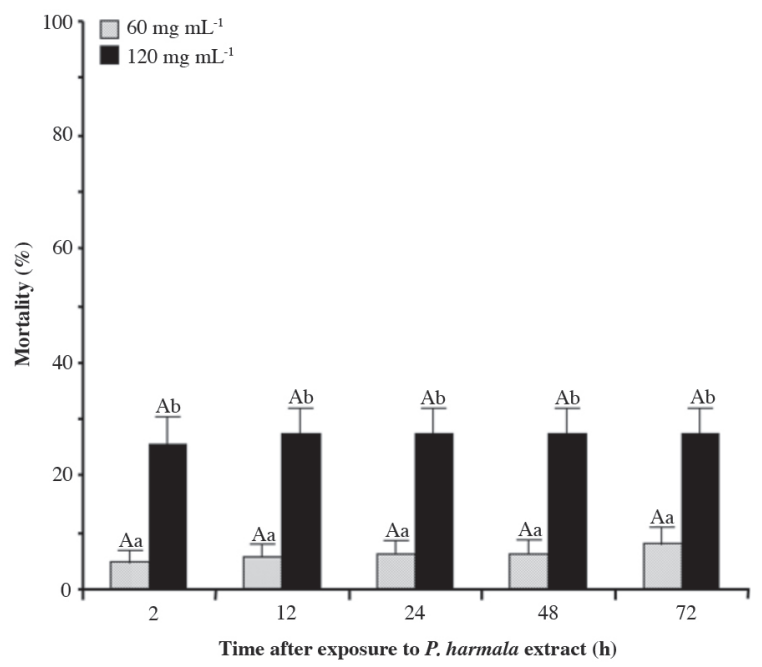

Bars with different lower case letters indicate significant differences between the different concentrations within the same time periods. Bars with different upper case letters indicate significant differences between the time periods within the same concentrations at $(\mathrm{P} \leq$ $0.05)$ (one-way ANOVA).

Figure 1. Mortality of two Peganum harmala acetonic seed extract concentrations on Tribolium castaneum after 2-72 h. stages of $M$. persicae. The repellent effect of $P$. harmala extract was with high RI on 1 - to 2-d-old $M$. persicae individuals $(\mathrm{RI}=72.8 \%)$, while it was $53.4 \%$ and $52.6 \%$ against adult and relatively susceptible 3 - to 4-d-old $M$.

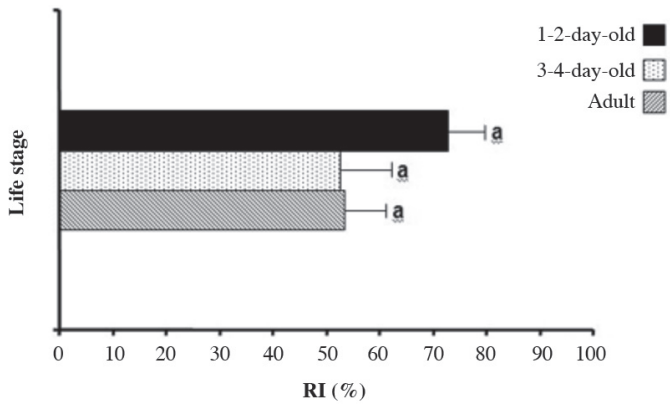

Figure 2. Repellent index (RI) of Peganum harmala acetonic seed extract against different developmental stages of Myzus persicae as determined in a dual choice bioassay after $48 \mathrm{~h}$.

persicae individuals, respectively, with intermediate RI. There were no significant repellent effects between developmental stages and adult treatments.

\section{DISCUSSION}

The most important finding of our study is the demonstrated toxicity of the seed extract on different aphid species. Comparing total mortality percentages of $P$. harmala acetonic seed extract on different treatments gives a good insight about its bioactivity. The $P$. harmala acetonic seed extract had a knockdown effect, which resulted in the sudden death of the treated insects, except A. nerii, after the extract was applied. At first, this extract caused moderate toxicity on A. nerii, but after a period of time, mortality increased remarkably, while it caused the highest mortality in A. gossypii after it was applied. The differences in insect mortality to the extract are perhaps related to its penetration and detoxification mechanisms. In the case of the aphid species, there seems to be greater activity against the more susceptible and smaller bulk of A. gossypii. Results revealed the insecticidal effect of $P$. harmala on different pests. Similar observations have been reported for other plant extract effects on several insects. The bioactivity of the harmala plant was shown by Abbassi et al. (2003), who reported that the alkaloids extracted by ethanol from $P$. harmala leaves caused significant mortality of the desert locust, $S$. gregaria, reduced female fecundity, as well as hatching rate when compared to the untreated control. Compared with our data, the Eichhornia crassipes (Pontederiaceae) extract delayed the development of the $4^{\text {th }}$ instar larva of $T$. castaneum and provoked its mortality (Rani and Jamil, 1989).

The insecticidal activity varied between insect species and exposure time. Our results showed that $P$. harmala acetonic extract was not very effective against $T$. castaneum after 3 d, while Jbilou et al. (2006) have reported that the methanol extract from $P$. harmala seeds had a high 
insecticidal effect on T. castaneum after $32 \mathrm{~d}$. This difference was probably due to the slow action of some plant extracts on Tribolium genus. Athanassiou et al. (2005) have reported that NeemAzal was not very effective against $T$. confusum Duval (Col., Tenebrionidae) where adult mortality was low even after $14 \mathrm{~d}$ of exposure at $200 \mathrm{ppm}$.

The results of applying $P$. harmala extract on different $M$. persicae life stages showed that this extract was highly repellent on $M$. persicae. Repellent effects on $M$. persicae have been reported by several authors. Gutiérrez et al. (1997) tested bisabolene, farnesol, and geraniol as aphid repellents against $M$. persicae in assays using apterous aphids and leaf discs embedded in agar. All three compounds showed activity, but only bisabolene was further tested because the others proved phytotoxic to Capsicum annuum L. (Solanaceae) leaves. Apparently farnesol may also have been toxic to the aphids. Park et al. (2005) demonstrated that several monoterpenes repelled the mosquito Culex pipiens pallens Coquillett (Diptera: Culicidae) and the nonoxygenated monoterpene a-terpinene is more repellent than the DEET commercial repellent. The mugwort Artemisia vulgaris L. (Asteraceae) also contains volatile insect repellents against the yellow fever mosquito Aedes aegypti (L.) Diptera: Culicidae) (Hwang et al., 1985). Hori (1998) and Bruce et al. (2005) found linalool was effective, but the response may vary with species. All three studies found that linalool repelled $M$. persicae, but it was not effective on Sitophilus avenae.

\section{CONCLUSIONS}

The $P$. harmala acetonic seed extract is potent and could be useful for aphid pest management in greenhouse plants because it was able to kill the treated pest through contact and oral toxicity, and it also acted as a strong insect repellent. This study is a preliminary investigation and its purpose was to compare the effect of a single rate of $P$. harmala acetonic seed extract against several pests. More studies are needed to bioassay the activity of other concentrations and each identified compound against aphid species and other pests.

Efecto tóxico y repelente del extracto acetónico de Harmal (Peganum harmala L.) sobre varias especies de áfidos y Tribolium castaneum (Herbst). Para reducir la dependencia de los pesticidas sintéticos en plantaciones frutales y hortalizas, se realizó un ensayo para medir la toxicidad y repelencia de un extracto acetónico obtenido a partir de semillas de Peganum harmala L. (Zygophyllaceae) contra diferentes especies de plagas. Para evaluar la toxicidad del extracto al contacto con los insectos, se incluyeron individuos de 3-4 d de edad de Aphis fabae Scopoli, Aphis gossypii Glover, Aphis nerii Boyer de Fonscolombe, y Myzus persicae (Sulzer), así como adultos 1-7 d de edad de Tribolium castaneum (Herbst). Experimentos para medir el efecto repelente se llevaron a cabo con individuos de 1-2 y 3-4 d de edad de M. persicae. En los resultados de los bioensayos tópicos el porcentaje de mortalidad fue significativamente mayor en la especie $A$. gossypii que en $A$. fabae y $A$. nerii, después de 12-72 h con una concentración de 60 $\mathrm{mg} \mathrm{mL} \mathrm{mL}^{-1}$. La mortalidad de los tratamientos contra $M$. persicae fueron $87,1 \%$ y $90,0 \%$ después de 24 y 48 h, respectivamente, la cual fue significativamente mayor que la obtenida con A.fabae y A. nerii durante el mismo período de tiempo. Con la concentración de $60 \mathrm{mg} \mathrm{mL}$ ${ }^{1}$, la mortalidad de $T$. castaneum fue muy inferior a las obtenidas con las diferentes especies de áfidos. El mayor índice de repelencia (mayor a 72\%) se observó en individuos de 1 a 2 d de edad de $M$. persicae entre los diferentes tratamientos.

Palabras clave: Peganum harmala, bioensayo tópico, áfidos, Tribolium castaneum, Aphis fabae, Aphis gossypii, Aphis nerii, Myzus persicae.

\section{LITERATURE CITED}

Abbassi, K., Z. Atay-kadiri, and S. Ghaout. 2003. Biological effects of alkaloids extracted from three plants of Moroccan arid areas on the desert locust. Physiological Entomology 28:232-236.

Abbott, W.S. 1925. A method of computing the effectiveness of an insecticide. Journal of Economic Entomology 18:265-267.

Athanassiou, C.G., D.C. Kontodimas, N.G. Kavallieratos, and M.A. Veroniki. 2005. Insecticidal effect of NeemAzal against three stored product beetle species on rye and oats. Journal of Economic Entomology 98:1733-1738.

Bughio, F.M., and R.M. Wilkins. 2004. Influence of malathion resistance status on survival and growth of Tribolium castaneum (Coleoptera: Tenebrionidae), when fed on flour from insectresistant and susceptible grain rice cultivars. Journal of Stored Products Research 40:65-75.

Bruce, T.J.A., M.A. Birkett, J. Blande, A.M. Hooper, J.L. Martin, B. Khambay, et al. 2005. Response of economically important aphids to components of Hemizygia petiolata essential oil. Pest Management Science 61:1115-1121.

Buckholtz, N.S., and W.O. Boggan. 1977. Monoamine oxidase inhibition in brain and liver produced by beta-carbolines: structureactivity relationships and substrate specificity. Biochemical Pharmacology 26:1991-1996.

Cox, P.D. 2004. Potential for using semiochemicals to protect stored products from insect infestation. Journal of Stored Products Research 40:1-25.

Frison, G., D. Favretto, F. Zancanaro, G. Fazzin, and S.D. Ferrara. 2008. A case of b-carboline alkaloid intoxication following ingestion of Peganum harmala seed extract. Forensic Science International 179:e37-e43.

Gutiérrez, C., A. Fereres, M. Reina, R. Cabrera, and C.A. González. 1997. Behavioral and sublethal effects of structurally related lower terpenes on Myzus persicae. Journal of Chemical Ecology 23:1641-1650.

Hori, M. 1998. Repellency of rosemary oil against Myzus persicae in a laboratory and in a screenhouse. Journal of Chemical Ecology 24:1425-1432.

Hwang, Y.S., K.H. Wu, J. Kumamoto, H. Axelrod, and M.S. Mulla. 1985. Isolation and identification of mosquito repellents in Artemisia vulgaris. Journal of Chemical Ecology 11:1297-1306.

Jbilou, R., A. Ennabili, and F. Sayah. 2006. Insecticidal activity of four medicinal plant extracts against Tribolium castaneum (Herbst) (Coleoptera: Tenebrionidae). African Journal of Biotechnology 5:936-940. 
Kartal, M., M.L. Altun, and S. Kurucu. 2003. HPLC method for the analysis of harmol, harmalol, harmine and harmaline in the seeds of Peganum harmala L. Journal of Pharmaceutical and Biomedical Analysis 31:263-269.

Kim, H., S.O. Sablin, and R.R. Ramsay. 1997. Inhibition of monoamine oxidase A by beta-carboline derivative. Archives of Biochemistry and Biophysics 337:137-142.

Kubo, I. 2006. New concept to search for alternate insect control agents from plants. p. 61-80. In Rai, M., and M. Carpinella (eds.) Naturally occurring bioactive compounds 3. Elsevier, Amsterdam, The Netherlands.

Lamchouri, F., A. Settaf, Y. Cherrah, M. El Hamidi, N. Tligui, B. Lyoussi, and M. Hassar. 2002. Experimental toxicity of Peganum harmala seeds. Annales Pharmaceutiques Francaises 60:123-129.
Park, B.S., W.S. Choi, J.H. Kim, K.H. Kim, and S.E. Lee. 2005. Monoterpenes from thyme (Thymus vulgaris) as potential mosquito repellents. Journal of the American Mosquito Control Association 21:80-83.

Pascual-Villalobos, M.J., and A. Robledo. 1998. Screening for anti-insect activity in Mediterranean plants. Industrial Crops and Products 8:183-194.

Rani, P.V., and K. Jamil. 1989. The effect of water hyacinth leaf extract on mortality, growth and metamorphosis of certain pests of stored products. Insect Science and Its Application 10:327-332.

Salari, E., K. Ahmadi, and R. Zamani. 2010. Study on the effects of acetonic extract of Otostegia Persica (Labiatae) on three aphid species and one stored product pest. Advances in Environmental Biology 4:346-349. 